\title{
Usaha Kuliner Berskala Mikro dan Kecil di Desa Gunung Sindur Kabupaten Bogor: Kondisi Pasca Covid-19
}

\author{
Ani Rakhmanita \\ Universitas Bina Sarana Informatika \\ e-mail: ani.ark@bsi.ac.id

\begin{tabular}{ccc}
\hline Diterima & Direvisi & Disetujui \\
$23-11-2020$ & $10-02-2021$ & $11-02-2021$ \\
\hline
\end{tabular}

\begin{abstract}
Abstrak - Pandemi Covid-19 menyebabkan masyarakat melakukan kegiatan di rumah saja untuk memutus mata rantai penyebaran virus sesuai dengan kebijakan pemerintah. Kebijakan tersebut pada akhirnya membuat banyak kegiatan yang memerlukan interaksi secara langsung harus dihindari dan membatasi kegiatan masyarakat untuk tidak keluar rumah. Di tengah keadaan yang tidak pasti, usaha kecil dan menengah, khususnya dibidang kuliner harus mampu beradaptasi secara cepat. Penelitian ini bertujuan untuk untuk mengetahui kemampuan dan pengetahuan dari sekompok usaha kuliner yang berada pada wilayah kabupaten bogor dalam beradaptasi di era pamdemi Covid-19. Metode penelitian yang digunakan adalah kualitatif deskriptif dengan mengunakan data primer dan data sekunder. Selanjutnya sumber data tersebut dianalisis secara deskriptip. Hasil penelitian ditemukan sebanyak $41,67 \%$ atau 10 pelaku usaha mengalami penurunan omset, omset stabil sebanyak $12,5 \%$ atau 3 pelaku usaha kuliner dan peningkatan penjualan sebanyak 45,83\% atau 11 pelaku usaha kuliner mengalami peningkatan omset penjualan. Strategi yang diterapkan usaha kuliner mikro dan kecil selama pandemik Covid didapatkan hasil diantaranya: (1) Menggunakan berbagai media social dan market place sebagai sarana berdagang (2) Mengganti produk yang relevan dengan kondisi kebutuhan pasar di era Covid (3) Memberikan promo dan discount menarik.
\end{abstract}

Kata kunci: UMKM, Covid-19, Strategi bertahan

The Covid-19 pandemic caused people to only carry out activities at home to break the chain of spreading the virus in accordance with government policy. In the end, this policy made many activities requiring direct interaction to be avoided and limited community activities from leaving the house. In the midst of uncertain circumstances, small and medium enterprises, especially in the culinary field, must be able to adapt quickly. This study aims to determine the abilities and knowledge of a group of culinary businesses in the Bogor Regency area in adapting to the Covid-19 pandemic era. The research method used is descriptive qualitative by using primary data and secondary data. Furthermore, the data sources were analyzed descriptively. The results of the study found that $41.67 \%$ or 10 business actors experienced a decrease in turnover, a stable turnover of $12.5 \%$ or 3 culinary business actors and an increase in sales of $45.83 \%$ or 11 culinary business actors experienced an increase in sales turnover. The strategies applied by micro and small culinary businesses during the Covid pandemic resulted in the following results: (1) Using various social media and market places as a means of trading (2) Replacing products that are relevant to market conditions in the Covid era (3) Providing attractive promotion and discounts.

Key words: SME, Covid-19,Survival strategy

\section{PENDAHULUAN}

Mewabahnya virus Covid-19 mengharuskan masyarakat melakukan kegiatan di rumah saja untuk memutus mata rantai penyebaran virus sesuai dengan kebijakan pemerintah. Kebijakan tersebut pada akhirnya membuat banyak kegiatan yang memerlukan interaksi secara langsung harus dihindari dan membatasi kegiatan masyarakat untuk tidak keluar rumah (Tuwu, 2020). Kondisi ini otomatis berpengaruh pada kegiatan ekonomi secara signifikan terhadap berbagai sektor industri terutama industry pabrik, industry wisata dan perhotelan serta transportasi (Sari, 2020). Di antara yang paling terpukul adalah usaha kecil dan menengah yang merupakan pengerak roda ekonomi negara. Banyak usaha kecil menengah yang menutup usaha sementara waktu dan menghadapi kendala arus kas (Baker and Judge, 2020). Dengan kondisi ini, Pelaku usaha kecil menengah harus segera beradaptasi dan mengkodisikan produk dan jasa layanan agar dapat bertahan terhadap pergeseran dan perubahan pola pembelian masyarakat selama pandemi dan setelah pandemi. 
Kemampuan beradaptasi dan bertahan lebih dimiliki oleh usaha kecil menengah karena dikelola secara langsung oleh para pemiliknya sehingga lebih luwes dalam beradaptasi terhadap perubahan lingkungan. Usaha kecil menengah tidak memiliki banyak beban tetap, sehingga terhindar dari kesulitan menanggung semua biaya pada kondisi ekonomi memburuk (Susilo, 2009). Pelaku usaha kecil menengah dibidang kuliner merupakan salah satu kelompok usaha yang dapat bertahan di tengah perubahan dan tidak mengenal masa serta tidak pernah mati, sehingga usaha ini pun selalu ada, di setiap tempat dan strata masyarakat. Makanan dan minuman masih menjadi kebutuhan pokok, dengan bentuk skala usaha besar maupun kecil. Dengan melihat kondisi dan kenyataan yang ada, maka usaha kuliner merupakan usaha yang sangat menjanjikan dan akan memberikan keuntungan maksimal (Amrullah, dkk, 2016). Permasalahan yang dihadapi oleh para pelaku usaha kuliner kecil menengah di tengah pandemic Covid-19, antaralain berkurangnya bahan baku, menurunnya penjualan, terhambatnya produksi dan distribusi, kesulitan permodalan serta kurangnya kemampuan dan pengetahuan tentang teknologi informasi (Fitriyani, dkk, 2020).

Kabupaten Bogor merupakan salah satu daerah otonomi yang dipimpin oleh seorang Bupati dan memiliki 40 kecamatan. Pandemi covid memberikan dampak negatif terhadap pertumbuhan ekonomi kabupaten Bogor, hal ini diungkapakan oleh wakil bupati bogor pada sidang paripurna istimewa di Ruang Paripurna Gedung DPRD kabupaten Bogor. Laju pertumbuhan ekonomi di daerah ini menurun sebesar 10,54 persen. Pada sektor Usaha mikro dan kecil dan menengah di Kabupaten Bogor dampak pandemi mempengaruhi penuruan omset hampir mencapai 70 persen. Berdasarkan data yang bersumber dari website https://umkm.bogorkab.go.id/, jumlah UMKM yang berada di wilayah Kabupaten Bogor tercatat sebanyak 2720 unit usaha dan diantara sebanyak 1.845 bergerak dibidang usaha kuliner. Berbagai penguatan program untuk meminimalisir dampak negative pada Usaha kecil dan menengah telah dilakukan oleh Pemerintah Kabupaten Bogor agar para pelaku usaha kecil dan menengah dapat bertahan menghadapi Pandemik covid-19.

Berdasarkan latar belakang diatas, penulis tertarik melakukan penelitian tentang strategi bertahan usaha kuliner kecil dan menengah pasca covid. Beberapa penelitian sejenis telah banyak mengkomfirmasi beberapa strategi bertahan yang dilakukan pelaku usaha kuliner kecil dan menengah. (Ulfa \& Puspasari, 2019) dalam penelitiannya mengungkapkan bahwa ada lima strategi yang dapat diterapkan oleh pelaku usaha kuliner dalam persaingan di industry kuliner, antaralain: Mempertahankan kualitas baik dari segi rasa.
Pemanfaatan teknologi, untuk mempermudah dalam melakukan promosi, Pemilihan tempat yang strategis untuk berjualan agar mempermudah pembeli untuk menemukan usaha. Pasrah dan berdoa dengan berserah diri kepada Tuhan dan Penglaris yang masih diterapkan oleh beberapa pelaku usaha di Kabupaten Ponorogo untuk memperoleh keuntungan.

Perbedaan terdapat pada penerapan strategi bertahan yang digunakan oleh penelitian terdahulu. Penelitian terdahulu hanya menggunakan strategi bertahan usaha kuliner pasca krisis moneter dan pada saat kondisi normal sedangkan penulis melakukan penelitian strategi bertahan usaha kuliner kecil dan menengah pasca pandemik covid di Desa Gunung Sindur. Penulis berharap penelitian ini dapat berkontribusi untuk memberikan bukti empiris di wilayah Gunung Sindur mengenai Kondisi Usaha Kuliner Kecil dan menengah Pasca Covid.

\section{METODE PENELITIAN}

Jenis penelitian ini bersifat deskriptif kualitatif. Penelitian kualitatif digunakan untuk lebih memahami dan menangkap fenomena sosial dari persepsi informan. Dalam penelitian ini difokuskan pada strategi adapatasi yang dilakukan oleh pelaku usaha kuliner mikro dan menengah di desa gunung sindur dalam mempertahankan eksistensi usahanya pasca Pandemi Covid-19. Penelitian deskriptif kualitatif adalah suatu metode yang digunakan untuk mendeskripsikan suatu hasil penelitian tetapi tidak digunakan untuk membuat kesimpulan yang lebih luas (Sugiono, 2009).

Pada penelitian ini, penulis tidak melakukan pengujian hipotesis, tetapi hanya ingin mengetahui keadaan variabel secara lepas dan tidak menghubungkan antar variable. Penulis menyelidiki secara cermat suatu fenomena sekelompok individu. Yang dibatasi oleh waktu dan aktivitas yang telah ditentukan (Creswell, 2012)

Parameter penelitian yang digunakan dalam penelitian ini lebih tertuju pada: Bagaimana dampak usaha kuliner mikro dan kecil Pasca covid-19 di Desa Gunung Sindur? Bagaimana strategi beradatasi usaha kuliner mikro dan kecil Pasca covid-19? Serta mendeskripsikan strategi yang dilakukan oleh pelaku usaha kuliner kecil menengah untuk dapat mempertahankan usaha mereka Pasca covid-19, sehingga para pelaku usaha kuliner kecil menengah ini mampu merubah ancaman menjadi tantangan. (Mohame et all, 2010)

Teknik pengumpulan data yang digunakan dalam penelitian ini adalah menggunakan kuisoner 
dalam bentuk Google form yang dibagikan kepada para pelaku usaha kuliner mikro dan menengah sebagai informan dalam penelitian ini, selanjutnya dilakukan wawancara mendalam kepada para informan dan dilanjutkan dengan observasi untuk mengamati dan mencatat strategi adapatasi yang dilakuakn oleh pelaku usaha kuliner mikro dan menengah di desa gunung sindur dalam mempertahankan eksistensi usahanya pasca pandemi Covid-19.

Sumber data yang digunakan adalah data primer yang diperoleh dari hasil angket google form berupa pertanyaan seperti jenis kelamin, usia, lamanya usaha berjalan, dampak pandemi terhadap usaha serta hasil wawancara dan observasi penerapan strategi beradaptasi yang diterapkan oleh informan untuk bertahan pasca pandemic covid-19. Sedangkan data sekunder bersumber dari jurnal dan referensi kepustakaan mengenai informasi yang terkait dengan penelitian.

Data yang telah dikumpulkan di lapangan tersebut diklasifikasikan untuk ditampilkan dalam bentuk tabel dan diagram yang lebih mudah dibaca. Selanjutnya dilakukan analisis data, analisa data yang digunakan adalah analisa data deskriptif kualitatif yaitu penyajian data dalam bentuk tulisan yang dihubungkan dengan hasil penelitian terdahulu. Selanjutnya hasil penelitian akan direkomendasi sebagai strategi yang dapat diadopsi oleh pelaku usaha kuliner mikro dan menegah.

Lokasi penelitian dilakukan di desa Gunung sindur kabupaten Bogor Jawa Barat. Dengan jumlah informan pada penelitian ini sebanyak 24 pelaku usaha kuliner kecil menengah. Usaha kuliner pada penelitian ini meliputi usaha bakso dan mie ayam, usaha Pecel ayam, pedagang sate, pedagang soto mie Bogor dan pelaku usaha oleh-oleh khas Bogor.

\section{HASIL DAN PEMBAHASAN}

Profil Informan yang menjadi populasi sekaligus sampel dalam penelitian ini adalah para pemilik usaha kecil dan menengah di desa Gunung sindur kabupaten Bogor yang bergerak dibidang usaha kuliner. Jumlah informan sebanyak 24 pelaku usaha yang tersebar di desa Gunung sindur. Penyebaran agket google form dilakukan di group whatsup komunitas UMKM Gunung Sindur. Komponen pertanyaan dalam angket terdiri dari tiga bagian. Bagian pertama berisi identitas informan yang terdiri dari jenis kelamin, usia, lamanya usaha. Bagian kedua mengenai pertanyaan dampak pandemi terhadap pelaku usaha kuliner yang terdiri dari tiga pertanyaan mengenai omset penjualan, hambatan pemasaran produk dan hambatan mendapatkan bahan baku. Bagian ketiga berisi pertanyaan terbuka terkait strategi beradapatasi dan bertahan yang dilakukan oleh pelaku usaha kuliner selama pandemi.

\section{Identitas Profil Informan}

Mayoritas informan dalam penelitian ini merupakan perempuan dengan presentase sebanyak $58 \%$. Sedangkan laki-laki hanya sebesar $42 \%$ (Gambar 1).

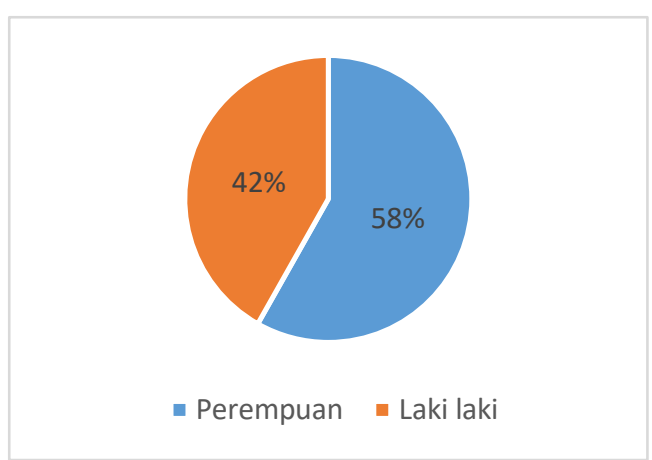

Sumber: Data diolah (2019)

Gambar 1. Jenis kelamin

Informan berusia 25-40 tahun sebanyak 64\% dan sisanya sebanyak $36 \%$ merupakan informan dengan rentang usia 40 tahun ke atas (Gambar 2). Peneliti mengelompokan 2 rentang usia menjadi 2 kelompok yaitu generasi $\mathrm{x}$ dan generasi milenial. Berdasarkan hasil obeservasi dan wawancara didapat bahwa pelaku usaha kuliner yang berada pada kelompok generasi milenial lebih banyak menerapkan pemesaran digital dibandingkan kelompok generasi $\mathrm{x}$.

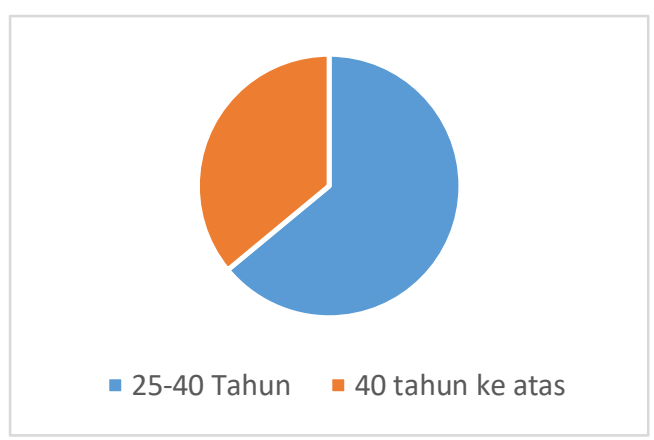

Sumber: Data diolah (2019)

Gambar 2. Usia

Dari lamanya usaha yang telah beroperasi ternyata sangat bervariasi (gambar. 3). Sebagian besar informan telah menjalankan usahanya $<5$ tahun sebanyak $32 \%$, Selanjutnya informan yang telah menjalankan usahanya selama $6-10$ tahun sebanyak $48 \%, 11-15$ tahun sebanyak $12 \%$ dan > 16 tahun sebanyak $8 \%$. Sebagian besar informan yang baru menjalankan $\leq 5$ tahun merupakan produsen 
minuman seperti kopi, jamu sehat dan minuman boba. Dominasi jenis kuliner minuman seperti disebutkan tadi merupakan pendatang baru yang sedang menjamur keberadaannya. Sisanya adalah jenis kuliner yang sudah lama ada, seperti bakso, pecel ayam, bubur ayam dan ketoprak.

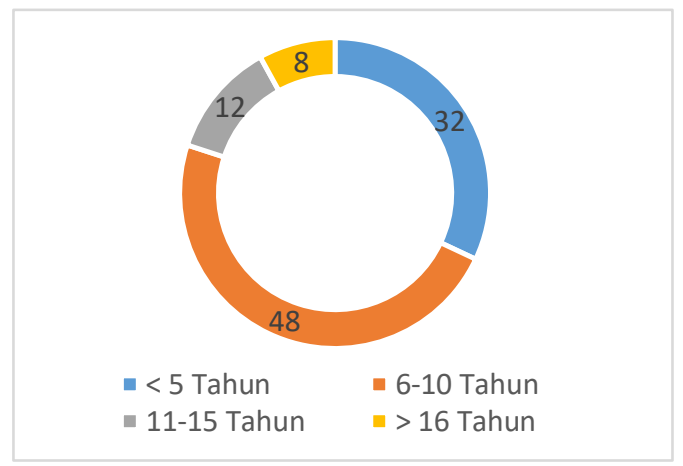

Sumber: Data diolah (2019)

Gambar 3. Lamanya usaha beroperasi

\section{Dampak pandemi Covid-19 terhadap Pelaku usaha kuliner di Desa Gunung Sindur Kabupaten Bogor}

Respon pelaku usaha kuliner mikro dan menengah terkait dengan pertanyaan dampak pandemi covid terhadap omset penjualan disajikan pada Gambar 4.

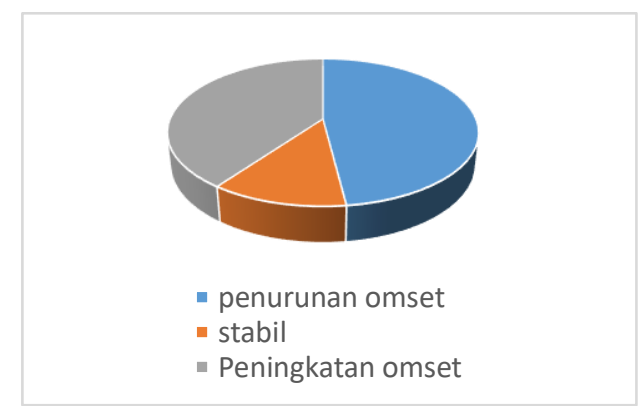

Sumber: Data diolah (2019)

Gambar 4. Dampak pademi terhadap Omset penjualan pelaku usaha kuliner

Berdasarkan hasil angket yang diberikan oleh para informan yang telah disebar melalui Google form terkait dampak usaha kuliner kecil dan Menengah di Desa Gunung Sindur Kabupaten Bogor selama pandeni Covid-19 ditemukan sebanyak $41,67 \%$ atau 10 pelaku usaha mengalami penurunan omset, omset stabil sebanyak $12,5 \%$ atau 3 pelaku usaha kuliner dan peningkatan penjualan sebanyak $45,83 \%$ atau 11 pelaku usaha kuliner mengalami peningkatan omset penjualan. Penurunan omset selama pandemi membuat Pelaku usaha kuliner mengalami keterpurukan dan kerugian, namun para pelaku usaha kuliner harus segera beradaptasi dengan menerapkan manajemen pemasaran yang lebih baik.

Respon pelaku usaha kuliner mikro dan menengah terkait dengan pertanyaan dampak pandemi covid terhadap kesulitan memasarkan produk disajikan pada Gambar 5.

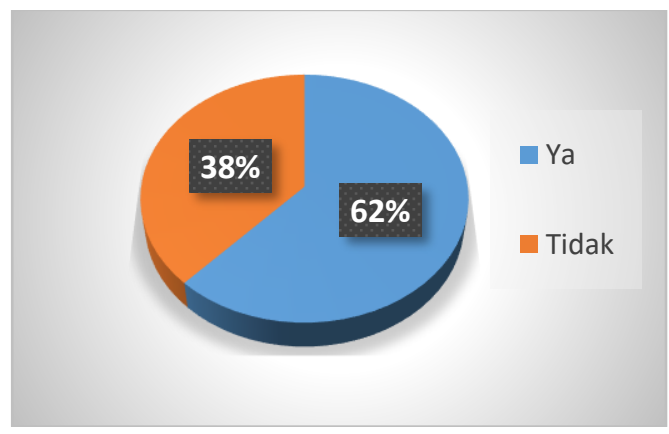

Sumber: Data diolah (2019)

Gambar 5. Dampak pandemic terhadap kesulitan memasarkan produk

Berdasarkan Gambar 5, diketahui bahwa pelaku usaha kuliner mikro dan menengah mengaku mengalami persoalan dalam memasarkan produknya sebesar $38 \%$ dan sebanyak $62 \%$ pelaku usaha kuliner dapat mengatasi persoalan memasarakan produknya dengan menggunakan digital marketing.

Respon pelaku usaha kuliner mikro dan menengah terkait dengan pertanyaan dampak pandemi covid terhadap kesulitan mendapatkan bahan baku mentah disajikan pada Gambar 6 .

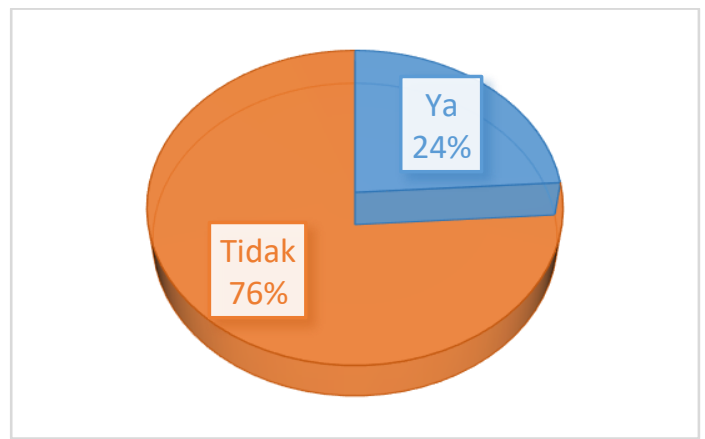

Sumber: Data diolah (2019)

Gambar 6. Dampak pandemic terhadap kesulitan mendapatkan bahan baku

Dari data yang tersaji pada Gambar 6 tersebut, dapat diketahui bahwa sebesar $76 \%$ pelaku usaha kuliner tidak mengalami kesulitan mendapatkan bahan baku. Namun demikian, sebesar 24\% mengakui kesulitan dalam medapatkan bahan baku. Banyaknya pelaku usaha kuliner yang mendapatkan kemudahan dalam mendapatkan bahan baku untuk usaha kulinernya disebabkan oleh lokasi usaha berada 
pada wilayah sumber bahan baku. Masih banyak terdapat peternakan dan perkebunan sayur mayur di desa Gunung Sindur yang menjadi mata pencaharian masyarakat setempat.

\section{Strategi beradatasi usaha kuliner mikro dan kecil selama COVID-19}

Untuk komponen pertanyaan strategi beradaptasi, penulis membuat pertanyaan terbuka terhadap pelaku usaha dan selanjutnya melakukan wawancara dan observasi secara mendalam terhadap pelaku usaha tersebut. Berdasarkan hasil pertanyaan terbuka pada angket tentang strategi beradaptasi usaha kuliner mikro dan kecil selama pandemik Covid didapatkan hasil bahwa yang diterapkan diantaranya: (1) Mengganti produk yang relevan dengan kondisi kebutuhan pasar di era Covid (2) Menggunakan berbagai media social dan market place sebagai sarana berdagang (3) Memberikan promo dan discount menarik. Dari data tersebut, penulis melakukan wawancara dan observasi secara mendalam terhadap 9 pelaku usaha yang memberikan jawaban menarik berkaitan tentang strategi mereka dalam beradaptasi selama pandemik.

Mengganti produk yang relevan dengan kondisi kebutuhan pasar di era Covid

Dari hasil observasi didapatkan bahwa 9 pelaku usaha kuliner mikro dan menengah sudah memahami pentingnya perubahan pola perilaku konsumen dalam berbelanja selama Pandemi Covid ini. Di tengah pandemi saat ini, segementasi pasar berubah dari gaya hidup menjadi kebutuhan dasar yang berhubungan dengan makan dan kesehatan. Pelaku usaha harus dapat menyesuaikan produk baru yang relevan dengan kondisi dan perilaku pasar dengan tetap memanfaatkan sumber daya dan bahan baku yang ada agar dapat bertahan. Strategi yang diterapkan oleh 9 informan adalah menciptakan produk makanan yang lebih tahan lama dan dikemas dengan desain menarik. Informan pada penelitian ini yang awalnya menjual makan yang dimasak fresh, saat ini menambahkan produk makanan frozen untuk masyarakat dalam menyetok persediaan bahan makanan selama pandemi. Hal ini dikarenakan aktivitas masyarakat lebih banyak di rumah dan dibatasi untuk keluar rumah. Hasil penelitian yang dilakukan oleh (Widyastuti, 2020) memperkuat penelitian ini bahwa Intensitas berbelanja responden dalam satu bulan adalah 1 hingga 2 kali. Jenis grocery store yang paling sering dikunjungi adalah supermarket dengan jenis produk makanan yang paling dominan dibeli adalah bahan makanan jadi atau kering (frozen). Pada penelitian tersebut diketahui prosentase terbesar dari responden adalah berjenis kelamin wanita dengan jenis pekerjaan yang didominasi sebagai Karyawan Swasta/BUMN/PNS.

\section{Menggunakan berbagai media social dan market place sebagai sarana berdagang}

Strategi lain yang diterapkan oleh pelaku usaha adalah Menggunakan berbagai media social dan marketplace sebagai sarana berdagang. Pemanfaatan media sosial online dan marketplace menjadi pilihan tepat bagi pelaku usaha kuliner mikro dan menengah untuk melakukan perdagangan dan pemasaran agar bisa tetap bertahan bahkan berpeluang dalam menjangkau pangsa pasar baru. Berdasarkan penelusuran lebih lanjut, sebagian besar informan yang telah memaksimalkan penggunaan berbagai media social dan market place sebagai sarana berdagang dan memasarkan produk menggunakan media social berupa: (1) media social Whatup (41,86\%) (2) media social Instagram $(23,26 \%)$, (3) media social Facebook $(12,79 \%)$. Informan sebanyak $86 \%$ yang belum menggunakan digital marketing dikarenakan ketidak mampuannya memanfaatkan teknologi informasi yang tersedia untuk meningkatkan omset penjualan. Minimnya pengetahuan, keterampilan, dan wawasan dalam teknologi informasi merupakan faktor-faktor yang melatar belakangi pelaku usaha tersebut belum menerapkan digital marketing. Penggunaan teknologi informasi di era pandemik covid-19 menjadi keharusan yang tidak mungkin dihindari dalam memasarkan produk. Hal ini menuntut pelaku usaha kuliner kecil menengah untuk dapat beradaptasi dengan kondisi saat ini salah satunya adalah mereka harus bisa memanfaatkan teknologi informasi dengan menggunakan media sosial. Hasil penelitian ini sejalan dengan riset yang dilakukan oleh (Wardhana,2015) yang menyatakan bahwa pemasaran digital berdampak positif terhadap keuanggulan bersaing usaha kecil menengah dalam memasarkan produknya. Strategi Pemasaran digital merupakan alternatif bagi usaha kecil dan menengah dengan anggaran promosi yang terbatas dan akan memberikan manfaat kepada konsumen dalam hal: kemudahan mencari produk, ketersediaan informasi produk atau artikel-artikel yang mendukung dan memberikan panduan produk bagi konsumen, ketersediaan tampilan testimonial, ketersediaan sajian informasi terbaru melalui sms-blog, ketersediaan bantuan pelayanan kepada konsumen, ketersediaan gambar-gambar pendukung yang dibutuhkan seperti foto-foto atau ilustrasi produk, ketersediaan tampilan video yang mampu memvisualisasikan produk atau presentasi-presentasi pendukung. (Stelzner, 2015) juga memperkuat temuan hasil riset ini, yang menyatakan media sosial berpotensi membantu pelaku usaha kecil dan menengah dalam memasarkan produk dan jasanya dalam hal jangkauan wilayah yang luas dan hemat biaya. Pelaku usaha kecil dan menengah dapat melakukan kegiatan pemasarannya seperti memperkenalkan produk, menjalin komunikasi dengan konsumen dan calon konsumen, dan memperluas jaringan bisnis melalui media social. 
Kegiatan memperkenalkan produk melalui media social dapat dilakukan oleh pelaku usaha kecil dan menengah dengan cara mempublikasikan video atau foto produk kuliner secara insentif. Penggunaan internet dan social media pada masyarakat di era pandemic semakin intens, sehingga masyarakat akan memiliki banyak pilihan yang lebih luas mengenai tujuan berbelanja, mereka akan lebih banyak untuk mencari tahu tentang produk, dan harga yang ditawarkan oleh berbagai penjual. Untuk itu pelaku usaha dituntuk untuk selalu belajar dan berfikir terbuka terhadap teknologi yang semakin berkembang.

\section{Memberikan promo dan discount menarik.}

Berdasarkan hasil observasi di lapangan, informan sebanyak $87 \%$ menerapkan strategi dengan memberikan promo dan discount untuk menarik pembeli. Penerapan strategi pemberian discount dilakukan pada waktu-waktu tertentu diantaranya di awal bulan dan di hari jumat. Alasan pemberian diskon di awal bulan adalah waktu di mana kebanyakan pembeli mendapatkan gaji. Jadi, akan lebih efektif, karena gaji tersebut masih belum banyak terpakai untuk kebutuhan sehari-hari. Sedangkan alasan pemberian diskon di hari jumat dikarenakan hari jumat adalah hari yang berkah bagi umat islam. Strategi pemberian diskon yang dilakukan oleh informan terbukti dapat meningkatkan penjualan dan hasil penelitian ini sesuai dengan penelitian yang dilakukan oleh (kusnanto et all, 2020) yang menyatakan bahwa pengaruh discount terhadap pembelian impulsif mahasiswa Program Studi Manajemen 2017 Fakultas Ekonomi dan Bisnis Universitas Singaperbangsa Karawang yang jadi pengguna apikasi Grab (GrabFood) dinyatakan berpengaruh positif. Berdasarkan hasil analisis lanjutan ditemukan bahwa pemberian discount akan mendorong pembeli melakukan pembelian impulsive atau tidak terencana. (Ekawati et al., 2020) juga memperkuat hasil penelitian ini dengan menyatakan bahwa variabel harga diskon berpegaruh berpengaruh positif dan signifikan terhadap minat beli konsumen pada restoran Saboten Shokudo.

\section{KESIMPULAN}

Penelitian ini bertujuan untuk mengetahui kemampuan dan pengetahuan dari sekompok usaha kuliner yang berada pada wilayah Gunung Sindur kabupaten bogor dalam beradaptasi di era pamdemi covid-19. Hasil penelitian menunjukkan bahwa sebagian besar responden yaitu $86 \%$ menerapkan beberapa strategi, antaralain: 1) Menggunakan berbagai media social dan market place sebagai sarana berdagang (2) Mengganti produk yang relevan dengan kondisi kebutuhan pasar di era Covid (3) Memberikan promo dan discount menarik. Strategi tersebut digunakan untuk mengatasi masalahmasalah dari adanya kebijakan kegiatan Adapun saran yang bisa direkomendasikan, antaralain: (1) Pelaku usha kecil dan menengah di bidang kuliner dapat menerapkan strategi merubah margin agar dapat berbertahan di era pandemik ini maupun dimasa yang akan datang. (2) Bagi Pemerintah wilayah Kabupaten Bogor, diharapkan terus memberikan edukasi dalam bentuk sosialisasi atau pelatihan kepada pelaku usaha kecil dan menengah. Membentuk jaringan komunikasi bagi UMKM sehingga mudah dipantau dan keterampilan UMKM akan semakin meningkat. (3)Penelitian ini memiliki keterbatasan data, penulis memiliki keterbatasan gerak dalam pengambilan data. Pengambilan data dilakukan hanya terbatas di wilayah Kabupaten Bogor dengan satu kecamatan saja, yang merupakan wilayah yang terdekat dengan tempat tinggal penulis. Untuk penelitian berikutnya, disarankan untuk melakukan pengambilan data dengan jangkauan wilayah yang lebih luas, sehingga dapat mengeneralisasi hasil penelitian.

\section{REFERENSI}

Amrullah, -, Hubeis, Musa, -, \& Sri, P. N. (2016). Strategi Pengembangan Bisnis Restoran Makassar Berbahan Baku Hasil Ternak dalam Mendukung Penyediaan Makanan Sehat (Studi Kasus di Restoran Marannu dan Karebosi Kelapa Gading). MANAJEMEN IKM: Jurnal Manajemen Pengembangan Industri Kecil Menengah, 11(1), 1-9. https://doi.org/10.29244/mikm.11.1.1-9

Baker, Todd, ., \& Judge, Kathryn, . (2020). How to Help Small Businesses Survive COVID-19. SSRN Electronic Journal, 620. https://doi.org/10.2139/ssrn.3571460

Creswell, J. . (2012). Research Design Pendekatan Kualitatif Kuantitatif dan Mixed. Pustaka Pelajar.

Ekawati, R. R., Saroh, .Siti, \& Zunaida, Daris, . (2020). Pengaruh Kualitas Layanan dan Harga Diskon Terhadap Minat Beli di Restoran Saboten Shokudo Kecamatan Klojen Kota Malang. Jiagabi, 9(1), 28-34.

Fitriyani,Ika,.Sudiyarti,Nining, . M. Nur Fietroh. (2020). STRATEGI MANAJEMEN BISNIS PASCA PANDEMI COVID-19. Indonesian Journal of Social Sciences and Humanities, 1(2), 101-108.

Kusnanto, Danang,. Abidzar Achmadtyar Fazrul Haq, Ilyan Sandrian Fahmi, . (2020). Pengaruh potongan harga terhadap pembelian impulsif pada pengguna aplikasi grab (grabfood). Jurnal Manajemen, 12(1), 1-9.

Mohamed, Z. M., Abdul Majid, A. H., \& Ahmad, N. (2010). Tapping new possibility in accounting research, in qualitative research in accounting. Penerbit Universiti Kebangsaan Malaysia,

Sari, Y. I. (2020). Sisi Terang Pandemi COVID-19. Jurnal Ilmiah Hubungan Internasional. 
https://doi.org/https://doi.org/10.26593/JIHI.V 0I0.3878.89-94

Stelzner, M. (2015). Social Media Marketing Industry Report How Marketers Are Using Social Media to Grow their Businesses (Issue May). Social Media Examiner.

Sugiono. (2009). Metode Penelitian Kuantitatif. Bayu Indra Grafika.

Susilo, Y. S. (2009). Strategi Bertahan Industri Makanan Skala Kecil Pasca. 110, 225-244.

Tuwu, D. (2020). Kebijakan Pemerintah Dalam Penanganan Pandemi Covid-19. Journal Publicuho, 3(2), 267-278. https://doi.org/10.35817/jpu.v3i2.12535

Ulfa, H., \& Puspasari, D. (n.d.). ( Studi Tentang Pelaku Usaha Kuliner Sate Ayam di Kabupaten
Ponorogo ).

Wardhana, Aditya, -. (2015). Strategi Digital Marketing dan Implikasinya Pada Keunggulan Bersaing UMK di Indonesia. Prosiding Seminar Nasional Keuangan Dan Bisnis IV, April 2015, 327-337.

Widyastuti, P. (2020). Analisis Keputusan Pembelian: Fenomena Panic Buying dan Service Convenience ( Studi pada Grocery Store di DKI Jakarta ). 978-979. 